\title{
FEMALE-TYPICAL SUBJECTS AND THEIR EFFECT ON WAGE INEQUALITIES AMONG HIGHER EDUCATION GRADUATES IN GERMANY
}

\section{Kathrin Leuze}

Department of Sociology, Leibniz University of Hannover, Hannover, Germany

\section{Susanne Strauß}

Department of Sociology, University of Tübingen, Tübingen, Germany

\begin{abstract}
In the search for an explanation of wage inequalities between men and women, it is often argued that women's disadvantages on the labour market are the result of their lower investment in human capital. However, this argument loses for at a time when highly educated women are outperforming men in terms of educational attainment. But even within the group of higher education graduates, gender differences remain in the form of gender-typical enrolment in academic subjects. The present article analyses the wage effects of how graduation in typically female subjects and subsequent work in typically female occupations generate wage inequalities 1 and 5 years after graduation. For understanding these effects, it follows the hypothesis of a socio-cultural devaluation of female-dominated subjects and occupations. Based on the 1997 HIS Absolventenpanel, we estimate gross hourly wages of male and female higher education graduates as they enter the German labour market. Results show that, 1 year after graduation, men receive a higher wage penalty than women for graduating in a femaledominated subject. However, working in typically female occupations affects women's wages more strongly than it does men's immediately after graduation. In addition, women have fewer possibilities to compensate for this penalty in subsequent years.
\end{abstract}

Key words: horizontal segregation; wage inequalities; higher education; gender; Germany

\section{Introduction}

One of the most profound labour market developments in OECD countries over the post-war period has been the continued progress made by women. Female employment has expanded considerably, and the 
employment gap relative to men has narrowed in virtually all countries. Germany too has seen a continuous rise of female labour force participation rates, from around $46.2 \%$ in 1970 to $66.1 \%$ in 2004 (Bothfeld et al. 2005: tables 3.A.1a, c). This general trend is often explained by changes in the labour supply behaviour of women, since a growing proportion of women remain in the labour market throughout their working lives and combine paid work with taking care of children and elderly relatives. In addition, structural changes in the economy such as the shift of employment from agriculture and manufacturing towards services, where female employment is concentrated, have favoured women's employment (OECD 2002: 66-8). However, the dramatic increase in women's average educational attainment is often considered the most important explanatory driver (Bassanini and Duval 2006). Today, the number of women who obtain tertiary qualifications is significantly higher than the number of men with higher education degrees in almost all OECD countries, and, compared to less educated women, employment rates are generally much higher among women with a tertiary degree (OECD 2009: 72, 129). Germany can be considered a latecomer regarding the female advantage in higher education: it was not before 2006 that female tertiary education graduates, with a share of $52 \%$, began to outnumber male graduates (OECD 2008: 90). Their share has been growing since, however.

These positive trends notwithstanding, important labour market inequalities among male and female higher education graduates persist: Female higher education graduates go through longer transition periods before obtaining a regular work contract (Smyth 2005), have lower chances of finding high status employment while bearing higher risks of becoming unemployed (Reimer and Steinmetz 2009), and, most importantly, earn considerably less than their male colleagues. In Germany, for example, female higher education graduates aged 30 to 44 on average earned 35 percentage points less per year than their male counterparts in 2008 (OECD 2009: A7.1b). Even though today both sexes obtain an equally high amount of education, wage differentials between men and women holding tertiary degrees start immediately after graduation. Yet little is known about the explanatory drivers behind this persisting inequality and its evolution in the first years after labour market entry. In this paper we therefore ask: Why do female higher education graduates earn less than their male counterparts upon leaving university? And how do wage inequalities between male and female graduates develop during the first 5 years after graduation?

One explanation for wage differences among the highly qualified - in addition to factors applying to women in general - is the gender-typical enrolment in academic subjects (Buchholz and Grunow 2006; Grunow 2006). In many countries, women tend to graduate in humanities, social 
sciences, and education, while men are generally overrepresented in natural sciences and in engineering (Machin and Puhani 2004; Charles and Bradley 2009). This pattern is also true for Germany, where, in $2007,74 \%$ of all humanities, arts and education students were female, while their share in mathematics and computer science was $33 \%$, and only $22 \%$ in engineering, manufacturing, and construction (OECD 2009: A3.6). Previous research has already shown that subjects studied by women yield lower labour market returns than those studied by men (Smyth 2005; Reimer and Steinmetz 2009). Thus, Görlitz and Grave (2012) find that wage differences between graduates from arts and humanities compared to natural sciences is $26 \%$, compared to engineering it is $40 \%$. The enrolment in different academic subjects also explains wage differences between male and female graduates in other OECD countries (Kalmijn and Van der Lippe 1997; Machin and Puhani 2004; Napari 2006). For Germany, Braakmann (2008: 2) concludes that about 74 to $76 \%$ of the difference in the entry-level salaries of men and women can be explained by gender differences in the choice of subject; 5 or 6 years after graduation, choice of subject still accounts for 26 to $33 \%$ of the gender wage gap.

Thus, it is old news that female graduates earn less than their male colleagues due to their enrolment in different academic subjects. However, this does not answer the question regarding the exact mechanisms at the bottom of wage inequalities that result from gender-specific subject enrolment. One explanation discussed in feminist theory assumes that individuals who graduated in 'female-typical' subjects or qualified for 'female-typical' occupations tend to face inferior career prospects because these subjects and occupations are valued less and are therefore paid less in the labour market. When testing this assumption, it is especially interesting to study higher education graduates at the beginning of their working lives: they are a relatively homogenous group regarding their acquired human capital, both in terms of years of education and labour market experience.

In the following, we start by presenting our theoretical assumptions on the effects of subject enrolment and occupational segregation for wage inequalities in more detail. After that, we test the derived hypotheses empirically by studying the case of Germany. Based on a representative sample of 1997 higher education graduates (HIS-Absolventenstudie 1997), we estimate the $\log$ gross hourly wages of men and women 1 and 5 years after graduation with random-effects panel models. In a first step, we analyse how female-typical subjects and occupational segregation affect wages. In a second step, we compare the relative influence of these factors 1 and 5 years after graduation and how they contribute to the development of wage inequalities among male and female higher education graduates. 
Wage inequalities between male and female university leavers with different subjects

Our theoretical concern is to understand how the enrolment in different subject areas might generate wage inequalities between male and female university leavers and how this influence changes during the years after graduation. We are thus less concerned with the process of how this enrolment comes about, e.g., whether it includes a rational choice or is due to socialisation processes. Instead, we aim at understanding the mechanisms which lead to wage inequalities between men and women due to the enrolment in different subject areas.

One of the most prominent theories for explaining wage differences between men and women is human capital theory. Its central assumption holds that more human capital leads to higher productivity and, consequently, to higher wages (Becker 1962). Wage differences between men and women are mainly explained by differences in years of education and labour market experience including further education at the work place (for an overview see Mincer 1974; Card 2001). Empirically, however, gender-specific wage differentials can only partly be attributed to differences in human capital (Kunze 2005; Braakmann 2008). Employment interruptions due to child rearing, shorter job tenure, less participation in firm-specific further training, and differences in vocational training are some of the factors which contribute to the lower levels of female human capital and therefore result in lower wages. Among recent university leavers, 17 to $18 \%$ of the gender wage gap are explained by such differences in human capital, since female graduates are more likely to change firms, have less work experience, are more often employed in marginal jobs or unemployed, and more often engage in child rearing activities (Braakmann 2008). In addition, human capital arguments are most suitable for understanding wage returns to different quantities of education, while more qualitative differences, as implied by variations in fields of study, are less within the scope of this theoretical framework. Generally, one can say that human capital theory argues within a rational choice framework which assumes the subject enrolment to be an individual's choice, based on a cost-benefit analysis.

In contrast, feminist cultural theories argue that the gender-typical enrolment in subjects associated wages can be explained by gendered socialisation processes (Jacobs 1989), which tend to reproduce gender stereotypes about what is considered typically male (e.g., analytical thinking in mathematics and natural sciences) or typically female (e.g., caring in educational and caring subjects) (Kelly 1985). Men and women are socialised to behave in accordance with pre-existing gender roles which influence their educational and occupational choices as well as their career 
plans (Correll 2001; Polavieja 2007). These gender-typical socialisation processes are supported and reproduced through the organisation of schools, peer influence, curricular content and teaching methods (Dekkers 1996; Dryler 1999; Smyth and Hannan 2002). Despite a substantial decline in sex segregation across academic subjects from the 1960s until the mid-1980s, brought on by women's entry into traditionally maledominated fields, men and women continue to be different in their preferences for fields of study (Jacobs 1995). Charles and Bradley (2002) argue that gender differences in subject choice are constructed and maintained by cultural beliefs of 'equal but different' (Charles and Bradley 2002: 575).

Choosing an academic subject based on gender-typical socialisation processes can lead to wage differences in labour markets that place a higher value on male-dominated subjects than on female-dominated ones. According to the approach of evaluative discrimination, the skills of lower status groups such as women or ethnic minorities are devalued (Baron and Newman 1990; Catanzarite 2003). The central idea is that, in the culture of western industrialised countries, women are valued less than men, which leads to a devaluation or stigmatisation of all things associated with women: styles of clothing, names, leisure activities or fields of study (Roksa 2005; England and Li 2006). Moreover, cultural gender role beliefs involve the idea that reproductive work, which is mainly provided without pay by women in the private sphere based on affection or family obligation, is considered less valuable when provided as paid work (Liebeskind 2004). In this view, female-typical fields of study are subject to devaluation. ${ }^{1}$ They can be expected to receive lower societal appreciation and, consequently, to result in lower wages for both male and female graduates.

H1a: A high representation of female students in a given field of study is associated with lower wages for graduates of this subject on the labour market.

However, the devaluation perspective implies an asymmetry in genderrelated returns. The stigma of graduating in a non-traditional academic subject is argued to be stronger for men than for women, because when

1. Evaluative discrimination is thus related to processes of devaluation due to horizontal segregation of fields of study. When, however, women and men with the same human capital (meaning academic subjects) are hired for different hierarchical positions and consequently receive different wages, we talk about allocative discrimination. Thus, men are ascribed more competence in leadership positions, since the cultural background of gender status beliefs (Ridgeway and Correll 2006) leads decision makers to perceive femininity and professional leadership as incongruent (Eagly and Karau 2002; Meng 2002). 
men enrol in a female subject, they are entering the devalued sphere of things associated with women (Williams 1995; England and Li 2006). When women enrol in a male subject, they are entering a sphere which western culture values more. England and Li (2006) trace this process by showing that the feminisation of fields of study discourages later cohorts of men (4 years later) from entering them. In a study on the sex composition of fields of doctoral receipt, England et al. (2007a) can show that it is not the prospect of declining relative salaries that deters men from entering certain fields of study, but rather the percentage of women enrolled in these fields, signalling their feminisation.

H1b. Men face higher wage penalties when graduating in female dominated subjects than women.

This gendered enrolment in academic subjects is not assumed to have an everlasting effect on individual wage development. Rather, the progression of a person's career can be expected to change the relative importance of educational credentials versus labour market experience in determining labour market success. According to the classical human capital equation, the influence of work experience relative to years of education increases over a person's employment career (Mincer 1974). As a consequence, the effect of a gender-typical enrolment in subjects should be particularly pronounced on labour market entry, but decrease in the course of further career development. This assumption is supported by findings of Machin and Puhani (2003), who show that the gender wage gap on entry to the labour market can be explained almost entirely by differences in fields of study, while fields of study seem to have little impact on wage growth.

H1c. The negative wage effect of female dominated subjects decreases in the first years after graduation for both sexes.

Yet after all, it could be the case that it is not graduating in a femaledominated subject that leads to lower wages, but that discrimination starts on the labour market, where female-dominated occupations are paid less than male-dominated ones. In the United States, for example, a certain decline in sex segregation across college majors has been observed, whereas sex segregation on the US labour market continues to be strong (Reskin 1993; Jacobs 1995; Bradley 2000). As to the underlying mechanisms, socio-cultural explanations suggest that female-associated activities at the workplace are devalued in ways similar to the devaluation of female-typical academic subjects. This means that it is not only fields of study but also occupations associated with women that are culturally devalued and consequently less well paid (England et al. 2002: 457). 
Female-typical jobs pay lower wages because employers are inclined to pay men more, either as a result of personal preferences, selective altruism toward male employees, or collusion. Moreover, female jobs pay less because employers make systematic cognitive errors when assessing the contribution that female occupations make to an organisation's profit or other goals. Finally, cognitive errors about the value of women's jobs persist because of framing effects, since present pay is in the frame used to assess the appropriateness of future pay (England 1992: 121-22). ${ }^{2}$

H2a: A high representation of women in a given occupation leads to lower wages for higher education graduates working in these occupations.

Again, the penalty for working in female-typical occupations should not be equally distributed between sexes. According to status characteristics theory, there are widely held cultural beliefs that men are more status worthy, influential, and competent than women (Ridgeway and Correll 2006). As a consequence, violating gender norms by working in a femaledominated occupation does not result in the same social sanctions for men as for women. For example, when co-workers and supervisors are uncomfortable with men violating gender norms, these men will tend to be pushed higher into organisational ranks and into leadership positions that are seen as appropriate for men (Williams 1995).

H2b: Men's wage penalty should be lower than the one of women in female dominated occupations.

Regarding changes in the course of one's career, research using cross-lag panel models supports devaluation theory by showing that jobs with a higher percentage of females have slower wage growth (or steeper wage decline) for both men and women in subsequent years (Karlin et al. 2002; England et al. 2007b). Again, however, it can be assumed from status characteristics theory that the long-term wage penalty from working in female-dominated occupations is larger for women than it is for men. This disparity may be attributed to supervisors' sex, since even if the majority of day-to-day co-workers in female-dominated occupations are women, supervisors are likely to be men. Therefore, men working in femaledominated occupations are more likely to receive workplace support or be offered a promotion because their supervisors, who are also likely to be

2. These findings contradict another prominent view supporting the opposite causal direction, namely that wage rate influences sex composition (Strober 1984; Reskin and Roos 1990). 
men, demonstrate an in-group preference for affiliating with in-group others (Williams 1995; Taylor 2010).

H2c. The wage penalty of female dominated occupations increases more strongly for women than for men during the first years after graduation.

\section{Data, method and variables}

In order to test our hypotheses, we conduct an analysis on the basis of a representative German panel study of the 1997 graduate cohort (HISAbsolventenpanel), which surveys higher education graduates about 1 (T1) and 5 (T2) years after graduation. The population consists entirely of higher education graduates who obtained their first degree at a German higher education institution. The study has been conducted since 1989 in 4-year intervals. Since 1993 it also includes graduates from East German institutions. ${ }^{3}$ For our analysis, we use the survey on individuals who graduated in 1997. ${ }^{4}$ The survey provides detailed information on respondents' higher education and their labour market trajectories during the first 5 years after graduation (for a detailed description of the data set, see Fabian and Minks 2006).

In order to assess gender differences in graduates' wages, we use random effects (RE) panel regressions to estimate logarithmised gross hourly wages. ${ }^{5}$ These regression models take into account the clustered nature of the data when two observations are available per person. Pooled

3. In order to account for the continuously different labour market situation, our models include a variable controlling for whether a person has a job in East or West Germany.

4. As a robustness check, we re estimated the models with data from the 2001 graduate cohort. The only remarkable descriptive difference is the larger share of women in the sample. As to our research question, we find largely the same results with the exception that the interaction between female dominated occupation and time is not significantly positive any more for women, i.e., neither men nor women can compensate the negative effect of female dominated occupations between T1 and $\mathrm{T} 2$. This is in line with findings that the phenomenon of the gender wage gap has been stable since the mid 1990s (Statistisches Bundesamt 2012).

5. In the HIS survey, respondents were asked about their gross monthly labour earnings at $\mathrm{T} 1$ and $\mathrm{T} 2$, but not for all employment spells since graduation. The choice to calculate hourly wages instead of monthly earnings aims at examining gender differences net of working hours (Petersen 1989). The possibilities to calculate hourly wages with HIS data are, however, somewhat limited since contractual working hours are only reported for part time workers. Therefore, full time workers are assigned 40 weekly working hours. The alternative option of estimating gross monthly earnings would have forced us to exclude part time workers in order to control for the working hours effect. Yet, this would have increased the problem of selectivity - especially regarding female working biographies at reproductive ages -, which exists anyway 
OLS standard errors and test statistics are generally invalid because they ignore the often substantial serial correlation in the error terms. Thus, RE models are considered more efficient than pooled OLS models (Wooldridge 2009: 493). The RE model calculates the influence of the explanatory variables on the dependent variable by including two error terms in the equation: the person-specific (time-constant) $a_{\mathrm{i}}$ and the errorterm $u_{i t}$ varying between individuals and time. In our case, we estimate the natural logarithm of the respondents' hourly wages:

$$
\ln (\text { wage })_{\text {it }}=\beta_{0}+\beta_{1} x_{i t 1}+\ldots+\beta_{k} x_{i t k}+a_{i}+u_{i t} ;
$$

where $\operatorname{Cov}\left(x_{i t j}, a_{i}\right)=0, t=1,2, \ldots T ; j=1,2, \ldots, k$. $a_{i}$, i.e., the timeinvariate person-specific error, is a random variable. $X_{1}-X_{k}$ denote the explanatory variables, including the field of study, the percentage of women in the subject and in the occupation and a variety of control variables. The assumption is - as in the OLS regression - that the error term is uncorrelated with the explanatory variables (here: at all time points). The alternative panel model approach, namely the fixed effects (FE) panel model, allows for correlation between person-specific error term and explaining variables. Since, however, FE models consider only variances within individuals over time, they exclude at the same time (mostly) time constant explanatory variables from the analysis. In our case, this allows us only to include sex-composition of occupations (and various control variables) in the FE model. In order to be able to include our timeconstant explanatory variables of interest (sex and sex-composition of subject), we decided to use RE panel models. ${ }^{6}$ One advantage of estimating logged wages is that the regression coefficients can be interpreted as percentage changes in wages (Wooldridge 2009: 43, 453).

As explanatory factors of the $\log$ gross hourly wages, we include in Model 1 the respondent's sex (women $=1$, men $=0$ ) as well as his or her field of study. The binary variable female represents the effect of being female versus being male on income, net of the other variables in the model. Since it is of special interest to examine the extent to which the coefficient for female changes across the various model specifications, we compare the coefficient for female in the bivariate baseline model with

since we focus on graduates in employment only. In addition, we excluded self employed individuals and those working abroad, since their wages are likely to be determined by mechanisms different from those graduates in dependent employment in Germany.

6. In order to check for differences between the results obtained by RE and FE models, we estimated FE models for the time varying covariates. These models show that the effects of occupational segregation are the same as in our RE model, they vary only somewhat in size. 
the female coefficient in each additional model. This allows us to assess the extent to which each of the possible explanations contributes to an understanding of gender wage inequalities. Academic subjects were subdivided into eight categories based on the ISCED classification (UNESCO 1997): humanities, arts, social sciences, law, economics, natural sciences, health and engineering. ${ }^{7}$

In the following models we analyse, separately at first, the influence of female-dominated subjects and occupations. For operationalising femaledominated subjects, we calculated the weighted mean female participation in a given subject (in percent) based on the detailed subject classification of the HIS survey and matched it to the respondents' fields of study. ${ }^{8}$ Similarly, to measure female-dominated occupations, we calculated the weighted mean share of women in each occupational category (in percent) of the 3-digit classification of the Federal Statistics Agency (KldB92) and merged it with graduates' occupations. This analysis was done on the basis of the German Microcensus (wave 2000 for T1 and 2002 for T2) with employed individuals aged 25 to 65 . Female-dominated subjects and occupations have a share of women of $70 \%$ and more, male-dominated ones of $30 \%$ and less, and integrated ones between 31 and $69 \% .{ }^{9}$ By following this approach, we assume that a high share of women makes the subject and the occupation appear female. ${ }^{10}$ All categories were included as dummy variables in the model (reference category: male-dominated subject or occupation). In Model 4 we include both explanatory factors.

Model 5 includes additional control variables, which previous research identified as having an influence on gender wage differences. These control variables can be divided into three groups. First, we include

7. Despite a more detailed coding of subject areas in the data set, we opted for this rough classification in order to allow for a sufficiently large number of respondents in each subject category.

8. We are aware that the analysis of sex segregation is sensitive to the number of fields of study entered in the analysis (Smyth 2005). Therefore, we used the more detailed field of study classification to define female dominated subjects (see Appendix A for the relationship between the detailed and rough classification as well as the percentage of women and the gender of each subject category).

9. The percentage of women required for an occupation to be considered female dominated has been discussed controversially. While Smyth (2005), for example, assumes a threshold of $60 \%$, Anker (1998: 80-6) suggests a stricter definition of between 70 and $75 \%$ female or male. We followed the latter suggestion; however, models with different specifications yielded similar results.

10. This operationalisation may, however, be criticised for not being able to differentiate between evaluative discrimination and mere crowding effects. In order to test the alternative explanation that women crowd in a relatively small number of occupations which they consider family friendly, we additionally control for the perceived family friendliness of the workplace. 
further indicators of the respondent's education biography and human capital: a completed apprenticeship, age at graduation (under 26, 26-29, 30 years and older), and the type of higher education degree attained. Here, we distinguish between 'Fachhochschule' degrees (i.e., degrees from a university of applied science), university degrees (Diplom and Magister), state examinations (Staatsexamen), and completed $\mathrm{PhD}$ degrees. Moreover, we control whether a respondent is involved in an ongoing $\mathrm{PhD}$ project or a practical training phase related to his or her studies. In addition, we include the number of further education courses taken during the first 5 years after graduation and a dummy controlling for student jobs which the respondent considers qualifying for his or her occupational area. Second, we include various variables capturing the respondent's labour market experience and current employment situation: length of unemployment and work experience (in months) since graduation, employment in East Germany, employment in a profession or in management, perceived family-friendliness of the workplace, and firm size (a dummy for large firms with over 500 employees), as well as employment in the public sector. Finally, we include various family characteristics, namely parental education (at least one parent with 'Abitur'), marital status (married or not), and having at least one child in the household, as well as the duration of family-related employment breaks (in months).

Based on Models 1 to 5, hypotheses H1a and H2a on the general effects of female-dominated subjects and occupations are tested. In order to trace the gender-specific influence of our explanatory variables on wages, as formulated in hypotheses $\mathrm{H} 1 \mathrm{~b}$ and $\mathrm{H} 2 \mathrm{~b}$, we calculate the full model for men and women separately (Models 6 and 7). For investigating the changing influence of gender-dominated subjects and occupations from 1 to 5 years after graduation and, thus, for testing hypotheses H1c and $\mathrm{H} 2 \mathrm{c}$, we additionally estimate the full model with interactions effects between $\mathrm{T} 2$ and our explanatory variables, first for all respondents and then separately for men and women. In the following section, we present the results of our empirical analysis.

\section{Empirical results}

Before estimating men's and women's wages upon their entry to the labour market, we first give an overview of the descriptive differences between male and female labour market entrants holding a higher education degree. Table 1 presents descriptive statistics for wages and the genderdomination of subjects and occupations.

The comparison of male and female hourly wages indicates that women earn significantly less than men at both time points of observation, since 
TABLE 1. Gender differences in wages, subjects, and occupations

\begin{tabular}{|c|c|c|c|c|c|c|}
\hline & \multicolumn{2}{|c|}{ Total } & \multicolumn{2}{|c|}{ Men } & \multicolumn{2}{|c|}{ Women } \\
\hline & Mean & SD & Mean & SD & Mean & SD \\
\hline Women & 0.44 & & & & & \\
\hline Gross hourly wage T1 & 13.18 & 5.14 & 14.49 & 4.78 & 11.42 & 5.07 \\
\hline Gross hourly wage T2 & 22.72 & 17.92 & 24.26 & 20.96 & 20.26 & 11.13 \\
\hline Female dominated subject & 0.19 & & 0.06 & & 0.35 & \\
\hline Integrated subject & 0.47 & & 0.41 & & 0.55 & \\
\hline Male dominated subject & 0.34 & & 0.53 & & 0.10 & \\
\hline Female dominated occupation T1 & 0.23 & & 0.15 & & 0.33 & \\
\hline Female dominated occupation T2 & 0.16 & & 0.10 & & 0.25 & \\
\hline Integrated occupation T1 & 0.37 & & 0.28 & & 0.48 & \\
\hline Integrated occupation T2 & 0.38 & & 0.28 & & 0.51 & \\
\hline Male dominated occupation T1 & 0.40 & & 0.57 & & 0.19 & \\
\hline Male dominated occupation T2 & 0.46 & & 0.63 & & 0.25 & \\
\hline
\end{tabular}

Source: HIS Absolventenpanel (Graduate cohort 1997), authors' calculations.

men's gross hourly wages increase from 14.49 euros at $\mathrm{T} 1$ to 24.26 euros at $\mathrm{T} 2$, while women start with lower gross hourly wages of 11.42 euros in $\mathrm{T} 1$ and earn 20.26 euros at T2. This finding suggests that even though women have caught up with men in terms of educational attainment, there is a substantial gender gap in wages among German higher education graduates right after graduation. What can also be noted is that the wage spread is comparatively small at the first interview $(S D=4.8$ for men and 5.1 for women) while it increases tremendously until the second interview, especially for men ( $S D=21.0$ for men, 11.1 for women). This development can be mainly explained with much steeper wage increases of male graduates as compared to their female counterparts. Also as expected, women are by far more often represented in female-dominated subjects, while men are over-represented in typical male subjects. This pattern suggests considerable sex segregation along academic subjects. Yet it is also obvious that a large number of men and women choose fields that are neither male- nor female-dominated. Sex segregation is also observable for the distribution of occupations at both time points of observation, even though the gap between men and women employed in female-dominated occupations narrows slightly during the first 5 years after graduation.

Given that women earn significantly less than men, we now turn to multivariate analysis to explore which factors contribute to gender wage differentials during the first 5 years after graduation. Table 2 presents the results of the random effects panel models on the log gross hourly wages. The baseline model (not shown), which includes the female coefficient, merely serves to confirm the general descriptive results, indicating that women on average earn 25 percentage points less than men when no 


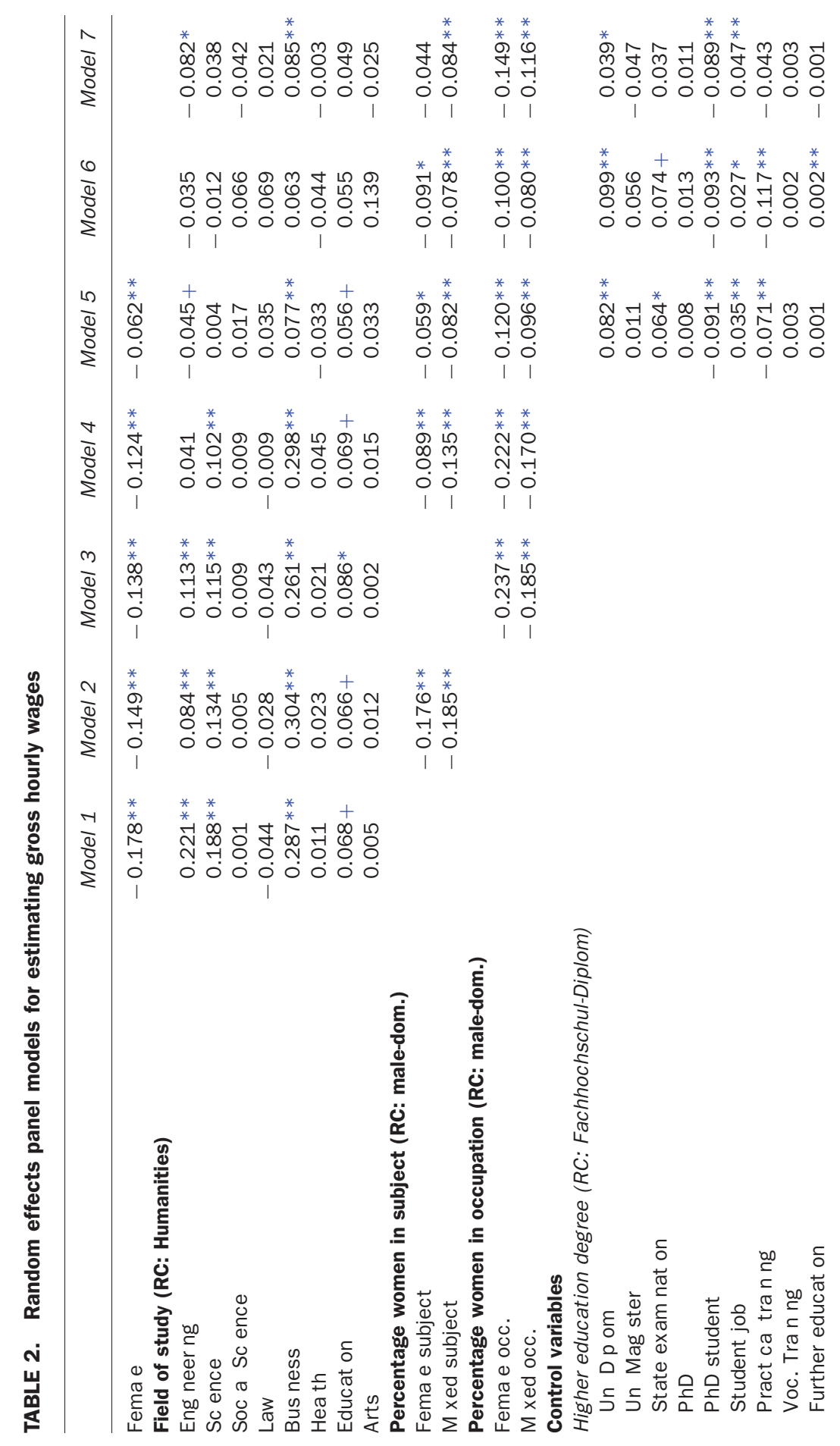




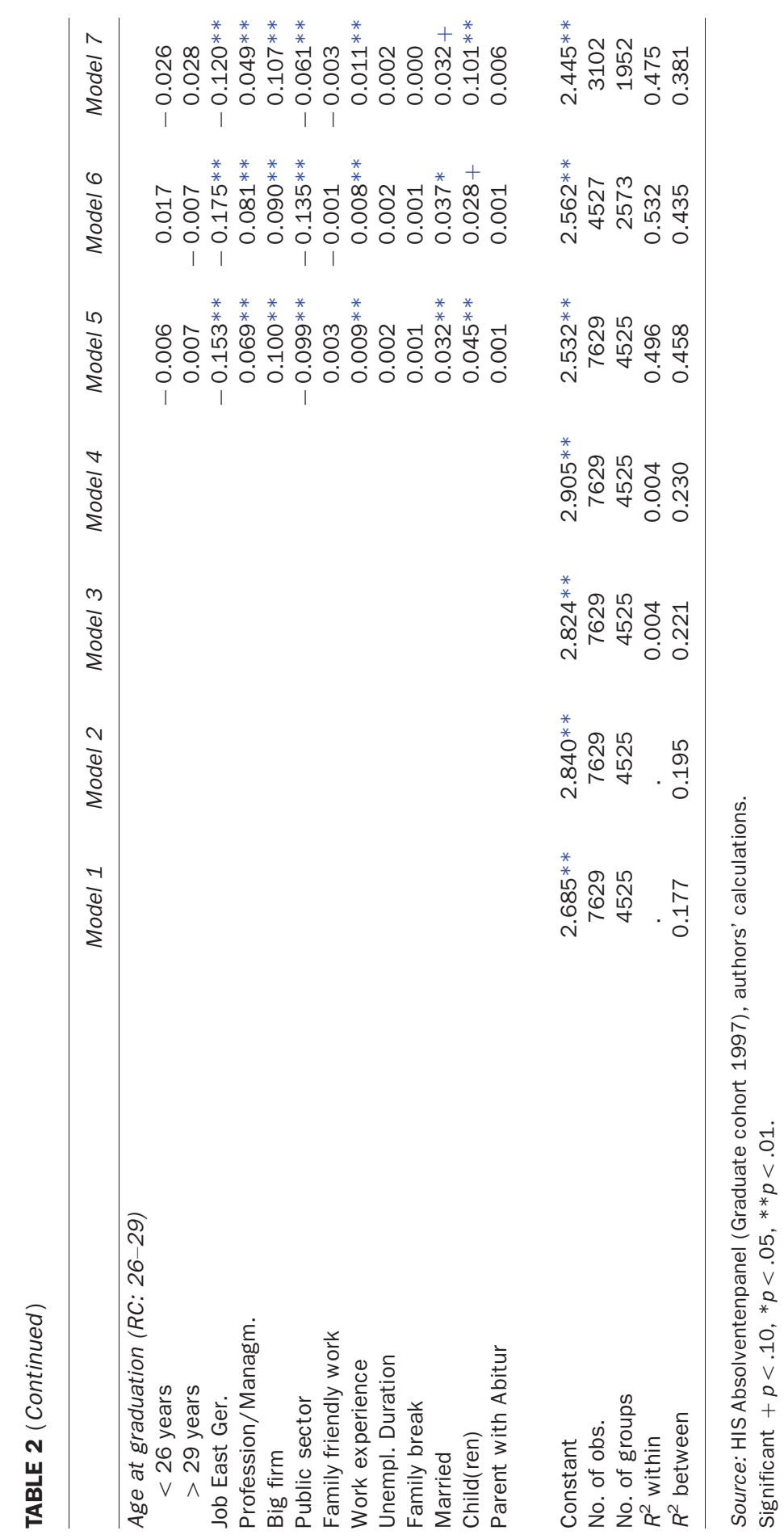


factors are controlled. This gender gap in wages is reduced to about 18 percentage points when controlling for subject areas (Model 1). At the same time, we observe a positive wage effect, regardless of a person's sex, of graduating in a natural science, engineering, or business subject compared to graduating in the humanities. Taken together, this suggests that women earn less than men because of their choice of subjects, as has been shown in previous studies on this topic (see, for example, Machin and Puhani 2004; Braakmann 2008).

As to the influence of sex-segregated subjects, Model 2 shows that a high share of female graduates in a given field of study reduces wages by about 18 percentage points. Similarly, sex segregation of occupations has a strong impact on wages (Model 3): graduates working in femaledominated occupations earn about 24 percentage points less than those in male-dominated occupations. Both findings confirm the predicted effect of the cultural devaluation of female-dominated subjects and occupations (hypotheses 1a and 2a), which leads to a wage penalty in the labour market. In addition, these models suggest that the gender composition of subjects and occupations has an influence on gender disparities in wages, since the female coefficient is found to decrease. In Model 4, which includes both sets of explanatory variables, the effects remain largely the same. Even though the coefficients for femaledominated subjects and occupations decrease in size, we still find a substantive negative effect on wages.

Taken together, the sex-typing of both subjects and of occupations contributes to gender wage inequalities during the first 5 years after graduation, since the gender wage gap decreases to about half of its size as compared to the empty model. The effects of female-dominated subjects and occupations stay largely the same after the inclusion of control variables, even though the effect size decreases again. However, even though we can explain about three-quarters of the initial gender wage differences by taking into account our explanatory and control variables, female higher education graduates still earn about 6 percentage points less than their male counterparts in our full model.

Finally, we estimate the same model separately for men and women (Models 6 and 7). As to the sex segregation of subjects, we find indeed that men are more penalised for studying a female-dominated subject than women. In fact, only men have lower wage returns when graduating in non-traditional subjects, whereas the effect for women becomes insignificant. As a consequence, we cannot any longer confirm in general that graduating in a female-dominated subject has a negative effect (H1a), but more specifically that the stigma of graduating in a female-dominated academic subject is much stronger for men than for women. Obviously, if 
men make a non-traditional choice, they are penalised for entering the devalued female sphere (H1b).

The opposite is found to be true for female-dominated occupations where women's wages are more negatively affected than men's wages ( 14.9 vs. $-10 \%$ wage decline). This serves to confirm the expected general negative effect of female-dominated occupations (H2a) and the assumption that women in female-dominated occupations are worse off than men $(\mathrm{H} 2 \mathrm{~b})$. This is in line with the expectation that widely held cultural beliefs about men being more status worthy, influential and competent than women help to buffer the negative effect for men working in non-traditional occupations.

In order to get a better understanding of how the influence of the different factors changes in the first 5 years after graduation, Table 3 presents the full model, including interaction effects for the main variables of interest with $\mathrm{T} 2$. The main effects are interpreted as influence at T1; the interaction effects indicate changes up to T2. First, we note that the gender wage gap which cannot be explained with our independent variables remains at about 6 percentage points and does not change significantly over time.

As to the influence of the sex-typing of subjects, we see again that men's wages are much more strongly affected from graduating in a femaledominated field of study than women's. At the same time, men have hardly any chances of compensating these wage losses during the first 5 years after graduation, since at $\mathrm{T} 2$, their wage loss due to graduating in a female-dominated subject does not decrease. This finding indicates that our hypothesis of a declining effect of female-dominated subjects over time (H1c) is neither true for men nor for women, but that the sex-typing of subjects has a lasting gender-differentiated effect. Men continue to be penalised for their atypical choice of subject, whereas women experience no wage losses when graduating in female-dominated subjects.

In contrast, women's wages are more strongly affected by working in female-dominated occupations. Wages are reduced by female-dominated occupations as early as 1 year after graduation in general, and the effect is stronger for women $(-22.6 \%)$ than for men $(-16.8 \%)$. But again, contrary to our expectations, we cannot show an increasing importance of this factor over time (H2c) for either sex. Rather, men and women are able to compensate for their initial losses to a certain extent (women by 13.1, men by $10 \%$ ). Yet the wage differential for women remains larger than the one for men even 5 years after graduation. This indicates that women in general are more penalised for working in female-dominated occupations than men, who possibly benefit from better workplace support from male supervisors and better chances for career progression. 
TABLE 3. Random effects panel models estimating gross hourly wages (interaction effects)

\begin{tabular}{|c|c|c|c|}
\hline & Model 8 & Model 9 & Model 10 \\
\hline Female & $-0.061 * *$ & & \\
\hline Female $*$ T2 & -0.007 & & \\
\hline \multicolumn{4}{|c|}{ Field of study (RC: Humanities) } \\
\hline Engineering & -0.025 & -0.043 & -0.020 \\
\hline Engineering $*$ T2 & -0.009 & 0.035 & $-0.094^{*}$ \\
\hline Science & 0.010 & -0.043 & $0.097 * *$ \\
\hline Science * T2 & 0.013 & 0.072 & -0.072 \\
\hline Social Science & $0.062+$ & 0.094 & 0.020 \\
\hline Social Science $*$ T2 & $-0.103^{*}$ & -0.053 & $-0.142 * *$ \\
\hline Law & -0.059 & -0.051 & -0.044 \\
\hline Law $*$ T2 & $0.158 * *$ & $0.210 * *$ & $0.106+$ \\
\hline Business & $0.111 * *$ & 0.057 & $0.161 * *$ \\
\hline Business * T2 & -0.024 & 0.040 & $-0.096 *$ \\
\hline Health & $-0.119 * *$ & $-0.186 * *$ & -0.039 \\
\hline Health $*$ T2 & $0.159 * *$ & $0.279 * *$ & 0.072 \\
\hline Education & 0.057 & 0.116 & 0.053 \\
\hline Education * T2 & 0.011 & -0.081 & 0.001 \\
\hline Arts & -0.019 & 0.049 & -0.049 \\
\hline Arts $*$ T2 & 0.091 & 0.156 & 0.040 \\
\hline \multicolumn{4}{|c|}{ Percentage women in subject (RC: male dom.) } \\
\hline Female subject & $-0.065^{*}$ & $-0.116 *$ & -0.025 \\
\hline Female subject $*$ T2 & 0.020 & 0.040 & -0.007 \\
\hline Mixed subject & $-0.122 * *$ & $-0.115 * *$ & $-0.128 * *$ \\
\hline Mixed subject $*$ T2 & $0.073 * *$ & $0.069 *$ & $0.087+$ \\
\hline \multicolumn{4}{|c|}{ Percentage women in occupation (RC: male dom.) } \\
\hline Female occ. & $-0.189 * *$ & $-0.168 * *$ & $-0.226 * *$ \\
\hline Female occ. * T2 & $0.116 * *$ & $0.100 *$ & $0.131 * *$ \\
\hline Mixed occ. & $-0.115 * *$ & $-0.083 * *$ & $-0.162 * *$ \\
\hline Mixed occ. * T2 & $0.060 * *$ & 0.028 & $0.105 * *$ \\
\hline Constant & $2.630 * *$ & $2.650 * *$ & $2.574 * *$ \\
\hline No. of obs. & 7629 & 4527 & 3102 \\
\hline No. of groups & 4525 & 2573 & 1952 \\
\hline$R 2$ within & 0.644 & 0.645 & 0.647 \\
\hline$R 2$ between & 0.513 & 0.480 & 0.457 \\
\hline
\end{tabular}

Source: HIS Absolventenpanel (Graduate cohort 1997), authors' calculations.

Significant $+p<.10, * p<.05, * * p<.01$.

Models control for the same control variables as models 5, 6 and 7 in Table 2.

\section{Discussion and conclusion}

The terrain of gender inequalities in education has seen much change in recent decades. While, in the mid 1990s, the main focus was still on female disadvantages (Jacobs 1996: 156), this is not the case anymore. Rather, much research now addresses the 'underachievement of boys' and ways in 
which girls have outpaced boys. This trend started in the United States, where women began to far outnumber men among higher education graduates in the late 1970s and early 1980s (Buchmann and DiPrete 2006). This same tendency, however, may also be observed in Europe (OECD 2009), leading to the emergence of new questions about gender inequalities in education and the labour market.

Our analysis began with the observation that women, their equal participation in tertiary education notwithstanding, continue to have problems transforming their acquired higher education credentials into wages equal to those of men. The issue which was addressed in this article is to investigate the role of gender-typical enrolment in different subject areas as well as gender-specific occupations for explaining wage inequalities between men and women in the first years after graduation.

Apart from the generally negative effect of female-dominated subjects and occupations on wages, we find a number of interesting gender differences: on the one hand, we can confirm the idea that men who have been enrolled in a female-dominated subject are especially penalised for this deviation as compared to women who graduated in a female subject. On the other hand, men working in female-dominated occupations are better off than women in such occupations. Following socio-cultural theories, we assume that the stigma for working in the devalued sphere of women is counterbalanced for men by their movement to higher hierarchical positions and more workplace support.

Finally, we were able to trace the changing influence of these factors over the first 5 years of higher education graduates' careers. Overall, we find more stability than change for both sexes. Five years after graduation, men continue to suffer from graduating in a female-dominated subject, while women do not experience such wage differentials. And even though the effects of female-dominated occupations decreases during the first 5 years after graduation for both sexes, the wage penalty remains larger for women than for men, indicating that men have again better chances of compensating their wage losses associated with the devalued sphere for female-typed occupations.

Overall, we thus confirm that fields of studies as well as occupations dominated by women are associated with lower monetary returns. This horizontal segregation thus contributes to continuing differences in wages between male and female higher education graduates. More specifically, female graduates' wages are negatively affected by working in a typically female occupation. Male graduates' wages, instead, are affected most by their non-traditional enrolment in female-dominated subjects. In their later careers, when entering female-dominated occupations, men are much more successful in achieving higher wages than their female counterparts, however. One can thus conclude that 
gender-specific subjects play an important role in explaining the gender wage gap among higher education graduates at the beginning of their working lives. At later stages of their career, the original influence of the academic subject decreases. This can be observed especially with men who opted for female-dominated subjects and enter female-dominated occupations but are financially more successful than their female counterparts working in the same occupations.

Generally, our results contribute to a deeper understanding of how the gender-typical enrolment in academic subjects affect gender wage inequalities and how these change during the first years after graduation from higher education. The findings of this study suggest that higher education continues to contribute to gender inequalities in a meaningful way despite women's overall success in education. However, since women have caught up with men in terms of participation in higher education, it is now more the horizontal segregation of men and women into different fields of study and occupations which contributes to wage inequalities between male and female higher education graduates.

\section{References}

Anker, R. (1998) Gender and Fobs. Sex Segregation of Occupations in the World, Geneva: International Labour Office.

Baron, J. N. and Newman, A. E. (1990) 'For what it's worth: Organizations, occupations, and the value of work done by women and nonwhites', American Sociological Reviem 55: 155-75.

Bassanini, A. and Duval, R. (2006) Employment Patterns in OECD Countries: Reassessing the Role of Policies and Institutions, Paris: OECD.

Becker, G. S. (1962) 'Investment in human capital: A theoretical analysis', The Fournal of Political Economy 70: 9-49.

Bothfeld, S., Klammer, U., Klenner, C., Leiber, S., Thiel, A. and Ziegler, A. (2005) WSI-FrauenDatenReport 2005. Handbuch zur mirtschaftlichen und sozialen Situation von Frauen, Berlin: Edition Sigma.

Braakmann, N. (2008) Non scholae, sed vitae discimus! - The Importance of Fields of Study for the Gender Wage Gap among German University Graduates during Labor Market Entry and the First Years of Their Careers, Lüneburg: University of Lüneburg.

Bradley, K. (2000) 'The incorporation of women into higher education: Paradoxical outcomes?', Sociology of Education 73: 1-18.

Buchholz, S. and Grunow, D. (2006) 'Women's emploment in West Germany', in Hans-Peter Blossfeld and Heather Hofmeister (eds), "Globalization, Uncertainty and Women's Careers. An International Comparison", Chelenham, Northampton: Edward Elgar. 
Buchmann, C. and DiPrete, T. A. (2006) 'The growing female advantage in college completion: The role of family background and academic achievement', American Sociological Reviem 71: 515-41.

Card, D. (2001) 'Estimating the returns to schooling: Progress on some persistent econometric problems', Econometrica 69: 1127-60.

Catanzarite, L. (2003) 'Race-gender composition and occupational pay degradation', Social Problems 50: 14-37.

Charles, M. and Bradley, K. (2002) 'Equal but seperate? A cross-national study of sex segregation in higher education', American Sociological Reviem 67: 573-99.

Charles, M. and Bradley, K. (2009) 'Indulging our gendered selves? Sex segregation by field of study in 44 countries', American fournal of Sociology 114: 924-76.

Correll, S. J. (2001) 'Gender and the career choice process: The role of biased self-assessments', American Fournal of Sociology 106: 1691-730.

Dekkers, H. (1996) 'Determinants of gender related subject choice: A longitudinal study in secondary education', Educational Research and Evaluation 2: 185-209.

Dryler, H. (1999) 'The impact of school and classroom characterstics on educational choices by boys and girls: A multilevel analysis', Acta Sociologica 42: 299-318.

Eagly, A. H. and Karau, S. J. (2002) 'Role congruity theory of prejudice toward female leaders', Psychological Reviem 109: 573-98.

England, P. (1992) Comparable Worth. Theories and Evidence, New York, NY: Aldine de Gruyter.

England, P., Allison, P., Li, S., Mark, N., Thompson, J., Budig, M. and Sun, H. (2007a) 'Why are some academic fields tipping toward female? The sex composition of U.S. fields of doctoral degree receipt, 1971-2002', Sociology of Education 80: 23-42.

England, P., Allison, P. and Wu, Y. (2007b) 'Does bad pay cause occupations to feminize, does feminization reduce pay, and how can we tell with longitudinal data?', Social Science Research 36: 1237-56.

England, P., Budig, M. and Folbre, N. (2002) 'Wages of virtue: The relative pay of care work', Social Problems 49: 455-73.

England, P. and Li, S. (2006) 'Desegregation stalled: The changing gender composition of college majors, 1971-2002', Gender E Society 20: $657-77$.

Fabian, G. and Minks, K.-H. (2006) Dokumentation des Scientific Use Files 'HIS Absolventenpanel 1997', Hannover: Hochschul-InformationsSystem.

Görlitz, K. and Grave, B. S. (2012) 'Wage differentials by field of study. The case of German University graduates', Education Economics 20: 284-302. 
Grunow, D. (2006) Convergence, Persistence and Diversity in Male and Female Careers - Does Con-text Matter in and Era of Globalization? A Comparison of Gendered Employment Mobility Patterns in West Germany and Denmark, Opladen: Barbara Budrich.

Jacobs, J. A. (1989) 'Long-term trends in occupational segregation by sex', Americal Fournal of Sociology 95: 160-73.

Jacobs, J. A. (1995) 'Gender and academic specialties: Trends among recipients of college degrees in the 1980s', Sociology of Education 68: $81-98$.

Jacobs, J. A. (1996) 'Gender inequality and higher education', Annual Reviem of Sociology 22: 153-85.

Kalmijn, M. and Van der Lippe, T. (1997) 'Type of schooling and sex differences in earnings in the Netherlands', European Sociological Reviem 13: 1-15.

Karlin, C. A., England, P. and Richardson, M. (2002) 'Why do "women's jobs" have low pay for their educational level?', Gender Issues 20: 3-22.

Kelly, A. (1985) 'The construction of masculine science', British Fournal of Sociology of Education 6: 133-54.

Kunze, A. (2005) 'The evolution of the gender wage gap', Labour Economics 12: 73-97.

Liebeskind, U. (2004) 'Arbeitsmarktsegregation und Einkommen - vom Wert "weiblicher" Arbeit', Kölner Zeitschrift für Soziologie und Sozialpsychologie 56: 630-52.

Machin, S. and Puhani, P. A. (2003) 'Subject of degree and the gender wage differential: Evidence from the UK and Germany', Economics Letters 79: 393-400.

Machin, S. and Puhani, P. A. (2004) The Contribution of Degree Subject to the Gender Wage Gap among Graduates: A Comparision of Britain, France and Germany, London: Anglo-German Foundation for the Study of Industrial Society.

Meng, C. (2002) '(Fe)Male jobs and (fe)male wages. Disentangling the effect of personal and job characteristics on wages by measuring stereotypes', Cahiers Économique de Bruxelles 45: 143-67.

Mincer, J. (1974) Schooling, Experience, and Earnings, New York/London: Columbia University Press.

Napari, S. (2006) The Early Career Gender Wage Gap, London: Centre for Economic Performance.

OECD (2002) Employment Outlook 2002, Paris: OECD Publishing.

OECD (2008) Education at a Glance 2008. OECD Indicators, Paris: OECD Publishing.

OECD (2009) Education at a Glance 2009. OECD Indicators, Paris: OECD Publishing. 
Petersen, T. (1989) 'The earnings function in sociological studies of earnings inequality: Functional form and hours worked', Research in Stratification and Mobility 8: 221-30.

Polavieja, J. G. (2007) 'The effect of occupational sex-composition on earnings: Job-specialization, sex-role attitudes and the devision of domestic labour in Spain', European Sociological Reviem 24: 199-213.

Reimer, D. and Steinmetz, S. (2009) 'Highly educated but in the wrong field?', European Societies 11: 723-46.

Reskin, B. (1993) 'Sex segregation in the workplace', Annual Reviem of Sociology 19: 241-70.

Reskin, B. and Roos, P. A. (1990) Fob Queues, Gender Queues: Explaining Women's Inroads into Male Occupations, Philadelphia, PA: Temple University Press.

Ridgeway, C. and Correll, S. J. (2006) 'Consensus and the creation of status beliefs', Social Forces 85: 431-53.

Roksa, J. (2005) 'Double disadvantage or blessing in disguise? Understanding the relationship between college major and employment sector', Sociology of Education 78: 207-32.

Smyth, E. (2005) 'Gender differentiation and early labour market integration across Europe', European Societies 7: 451-79.

Smyth, E. and Hannan, C. (2002) Who Chooses Science? Subject Take-up in Second-level Schools, Dublin: Liffey Press/ESRI.

Strober, M. H. (1984) 'Towards a general theory of occupational sex segregation: The case of public school teaching', in B. F. Reskin (ed.), Sex Segregation in the Workplace: Trends, Explanations, Remedies. Washington, DC: National Academy Press.

Taylor, C. J. (2010) 'Occupational sex composition and the gendered availability of workplace support', Gender ES Society 24: 189-212.

UNESCO (1997) International Standard Classification of Education ISCED 1997, Paris: UNESCO.

Williams, C. L. (1995) Still a Man's World: Men Who Do 'Women's Work', Berkeley, CA: University of California Press.

Wooldridge, J. M. (2009) Introductory Econometrics. A Modern Approach, 4th edition, Mason, $\mathrm{OH}$ : Thomson

Kathrin Leuze is a full professor of Education Sociology at the Institute of Sociology of the Leibniz University of Hannover. She received her PhD from the Graduate School of Social Sciences (GSSS) at the University of Bremen in 2007 . She is interested in quantitative life course research with special emphasis on higher education, employment biographies, gender inequalities and cross-national comparisons. 
Susanne Strauß is an assistant professor of Sociology at the Institute of Sociology of the University of Tuebingen. She received her PhD from the Graduate School of Social Sciences (GSSS) at the University of Bremen in 2007. Her research interests are: quantitative life course research with special emphasis on employment biographies, old age security, gender inequality and civic engagement.

Address for correspondence: Prof. Dr. Kathrin Leuze, Institute of Sociology, Leibniz University of Hannover, Schneiderberg 50, 30167 Hannover, Germany.

E-mail: k.leuze@ish.uni-hannover.de

Appendix A: Description of subjects

\begin{tabular}{|c|c|c|c|}
\hline Major category & Minor category & $\begin{array}{c}\text { Percentage } \\
\text { female }\end{array}$ & Gender \\
\hline \multirow[t]{2}{*}{ Education } & Education & 85.37 & Female \\
\hline & Special education & 76.51 & Female \\
\hline \multirow[t]{14}{*}{ Humanities } & Protestant theology & 53.01 & Integrated \\
\hline & Catholic theology & 54.65 & Integrated \\
\hline & Philosophy & 22.38 & Male \\
\hline & History & 50.48 & Integrated \\
\hline & Library science & 68.53 & Integrated \\
\hline & Linguistics and literature & 59.20 & Integrated \\
\hline & Classical philology & 63.71 & Integrated \\
\hline & German studies & 84.06 & Female \\
\hline & English studies & 78.67 & Female \\
\hline & Romance studies & 96.54 & Female \\
\hline & Slavic studies & 86.53 & Female \\
\hline & Non European languages & 63.45 & Integrated \\
\hline & Cultural studies & 78.28 & Female \\
\hline & Language and culture & 98.56 & Female \\
\hline \multirow[t]{5}{*}{ Health } & Psychology & 68.73 & Integrated \\
\hline & Sport science & 58.02 & Integrated \\
\hline & Medicine & 54.50 & Integrated \\
\hline & Dentistry & 37.71 & Integrated \\
\hline & Veterinary medicine & 78.16 & Female \\
\hline \multirow[t]{6}{*}{ Engineering } & Industrial engineering & 18.39 & Male \\
\hline & Landscape planning & 60.19 & Integrated \\
\hline & Agrarian food science & 38.75 & Integrated \\
\hline & Forestry & 7.48 & Male \\
\hline & Food and household science & 82.58 & Female \\
\hline & Engineering & 60.57 & Integrated \\
\hline
\end{tabular}


Appendix A (Continued)

\begin{tabular}{|c|c|c|c|}
\hline Major category & Minor category & $\begin{array}{c}\text { Percentage } \\
\text { female }\end{array}$ & Gender \\
\hline & Mining & 2.22 & Male \\
\hline & Mechanical engineering & 11.72 & Male \\
\hline & Electrical engineering & 4.36 & Male \\
\hline & Traffic engineering & 0.00 & Male \\
\hline & Architecture & 56.10 & Integrated \\
\hline & Regional planning & 44.14 & Integrated \\
\hline & Construction & 24.71 & Male \\
\hline & Surveying & 24.05 & Male \\
\hline \multirow[t]{4}{*}{ Arts } & Arts & 87.92 & Female \\
\hline & Design & 55.42 & Integrated \\
\hline & Performing arts & 74.67 & Integrated \\
\hline & Music & 58.03 & Integrated \\
\hline \multirow[t]{9}{*}{ Natural sciences } & Mathematics - natural science, general & 75.00 & Female \\
\hline & Mathematics & 48.40 & Integrated \\
\hline & Computer science & 15.45 & Male \\
\hline & Physics, astronomy & 16.15 & Male \\
\hline & Chemistry & 34.81 & Integrated \\
\hline & Pharmacy & 82.51 & Female \\
\hline & Biology & 66.37 & Integrated \\
\hline & Geoscience & 23.07 & Male \\
\hline & Geography & 46.93 & Integrated \\
\hline Law & Law & 45.89 & Integrated \\
\hline \multirow[t]{5}{*}{ Social sciences } & Economics and social sciences & 27.91 & Male \\
\hline & Regional sciences & 97.28 & Female \\
\hline & Political sciences & 56.16 & Integrated \\
\hline & Social sciences & 65.71 & Integrated \\
\hline & Social work & 81.26 & Female \\
\hline \multirow[t]{2}{*}{ Economics } & Public administration & 10.82 & Male \\
\hline & Economics & 46.20 & Integrated \\
\hline
\end{tabular}

